http://jmscr.igmpublication.org/home/ ISSN (e)-2347-176x ISSN (p) 2455-0450

crossref DOI: https://dx.doi.org/10.18535/jmscr/v7i12.69

\title{
Ocular Manifestations in Multi-Transfused Children with Beta Thalassemia Receiving Chelating Agents
}

\author{
Authors \\ Dr Shantala Arunkumar ${ }^{1}$, Dr Ruchi Sood ${ }^{2}$, Dr Latha G $S^{3}$ \\ ${ }^{1}$ Professor \& HOD S.S Institute of medical sciences And Research Centre, Davangere, Karnataka, \\ ${ }^{2}$ Post Graduate, S.S Institute of Medical Sciences And Research Centre, Davangere, Karnataka \\ ${ }^{3}$ Professor Department of Paediatric, S.S Institute of Medical Sciences and Research Centre, Davangere, \\ Karnataka
}

\begin{abstract}
Purpose: To determine prevalence of ocular abnormalities in children with beta thalassemia and assess the ocular side effects of blood transfusion and iron chelating agents.

Methods: Cross sectional study undertaken over a period of one year among $30 \beta$ Thalassemia major patients from age group of 6 months to 18 years were taken. Full medical history, thorough physical examinations were done to all patients groups, and ophthalmological examination to determine the prevalence of ocular manifestations for all patient groups and to correlate these manifestations or changes with iron chelating agents. Ocular examination including near and distance visual acuity assessment with Snellen's charts, colour vision testing, external examination with diffuse illumination, slit-lamp examination, direct and indirect ophthalmoscopy, schrimer test for tear break up time and ocular biometry will be performed.

Results: In 30 patients (16 females and 14 males) with age ranging between 2 years to 18 years. The prevalence of ocular abnormalities was 40\%, (12/30). Ocular changes seen included decreased visual acuity 50\% (6/12), ocular surface disorder 23\%(7/12), lenticular opacity 16.5\% (2/12), blurred optic disc margins $16.5 \%$ (2/12) and dilatation and tortuosity of retinal vessels 33\% (4/12), Retinal pigment epithelium mottling 8\%(1/12). The mean serum ferritin and the number of blood transfusions received were higher in children with ocular findings than in those with no ocular manifestations.

Conclusion: Ocular findings in beta-thalassemia may correlate to the disease itself, iron overload or the chelating agents used.Children with beta-Thalassemia develop various eye problems and Ocular changes are attributed to the course and severity of the disease. Therefore, beta thalassemia children should be screened periodically to enable early detection and delay of ocular changes.
\end{abstract}

\section{Introduction}

Thalassemias are the most common single gene disorder worldwide. Mutations involving the beta globin gene in beta-thalassemia cause disruption in red blood cell maturation leading to ineffective erythropoiesis and multi-system involvement. Ineffective erythropoiesis leads to severe anemia which is treated by regular blood transfusion to maintain hemoglobin at or above $10 \mathrm{mg} / \mathrm{dl}$. Multiple/repeated blood transfusions lead to siderosis ${ }^{1}$. More than 42,000 newborns are affected by Beta- thalassemia every year worldwide. Without blood transfusions, betathalassemia major causes death amongst affected 
children before the age of three years ${ }^{2}$. Ocular changes like ocular surface disorders, cataract, optic neuropathy, retinal pigment epithelial degenerations, retinal venous tortuosity, vitreo retinal haemorrhages are noted. This study was conducted to assess the ocular abnormalities in multi-transfused beta- thalassaemic Indian children and to determine their relationship with iron overload, chronic hypoxia, age, the dosage and duration of treatment with chelating agents.

\section{Aims and Objective}

Study the ocular abnormalities in betathalassemia major patients.

* Assess the ocular side-effects of blood transfusions and iron chelating agents.

\section{Method of Study}

We conducted a cross sectional over a period of one year among 30 children with beta-thalassemia from age group of 6 months to 18 years attending the thalassemia clinic of the paediatric department of a tertiary care centre.

\section{Inclusion Criteria}

Children diagnosed with Beta thalassemia major with or without Blood transfusion.

\section{Exclusion Criteria}

* Children with previous ocular morbidity.

* Trauma

* Active ocular infections

* Haemoglobinopathies other than beta thalassemia

An informed consent for participation was obtained from parents or legal guardians. The diagnosis of beta-thalassemia major will be confirmed by clinical and hematological studies.Data was collected in form of detailed medical history, Ironchelating agents: dose, duration and serum ferritin levels, thorough physical examination \& Ophthalmological examination by an ophthalmologist included:

Visual acuity

Refraction testing

Slit-lamp examination

Colour vision testing
External examination with diffuse illumination and slit-lamp examination

Fundoscopy by both direct and indirect ophthalmoscope

Schirmer test and Tear break up time

\section{Results}

In 30 patients (16 females and 14 males) with age ranging between 2 years to 18 years. The prevalence of ocular abnormalities was $40 \%$ (12/30). Ocular changes seen included decreased visual acuity (5/30), ocular surface disorder (7/30), lenticular opacity (2/30), blurred optic disc margins (2/30) and dilatation and tortuosity of retinal vessels (4/30), Retinal pigment epithelium mottling (1/30).

Table 1: Serum Ferritin and ocular Manifestations

\begin{tabular}{|l|c|c|}
\hline SERUM FERRITN & $\begin{array}{c}\text { NO. OF SUBJECTS } \\
(\mathrm{N}=30)\end{array}$ & $\begin{array}{c}\text { OCULAR } \\
\text { INVOLVEMENT }\end{array}$ \\
\hline LESS THAN 1000 & 4 & $0(0 \%)$ \\
\hline $1000-3000$ & 10 & $3(30 \%)$ \\
\hline $3000-5000$ & 9 & $5(55.4 \%)$ \\
\hline 5000 OR MORE & 7 & $4(57.2 \%)$ \\
\hline
\end{tabular}

Table 2: Chelation dose and ocular manifestations

\begin{tabular}{|l|c|c|}
\hline Dose of chelating agent & $\begin{array}{c}\text { N0. OF SUBJECTS } \\
(\mathrm{N}=30)\end{array}$ & $\begin{array}{c}\text { OCULAR } \\
\text { NVOLVEMENT }\end{array}$ \\
\hline$<20 \mathrm{mg} / \mathrm{kg} / \mathrm{day}$ & 8 & $2(25 \%)$ \\
\hline $20-30 \mathrm{mg} / \mathrm{kg} / \mathrm{day}$ & 10 & $4(40 \%)$ \\
\hline$>30 \mathrm{mg} / \mathrm{kg} / \mathrm{day}$ & 12 & $6(50 \%)$ \\
\hline
\end{tabular}

Table 3: Age Relation with Ocular Manifestations

\begin{tabular}{|l|c|c|}
\hline \multicolumn{1}{|c|}{ AGE } & $\begin{array}{c}\text { N0.0F SUBJJCTS } \\
(\mathrm{n}=30)\end{array}$ & $\begin{array}{c}\text { OCULAR } \\
\text { NVOLEMENT }\end{array}$ \\
\hline Less than 5 years & 4 & $1(25 \%)$ \\
\hline $5-10$ years & 14 & $4(28.5 \%)$ \\
\hline $11-18$ years & 12 & $7(58.3 \%)$ \\
\hline
\end{tabular}




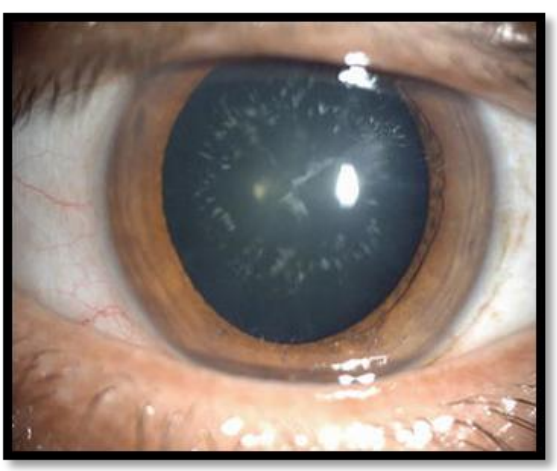

Lenticular opacity

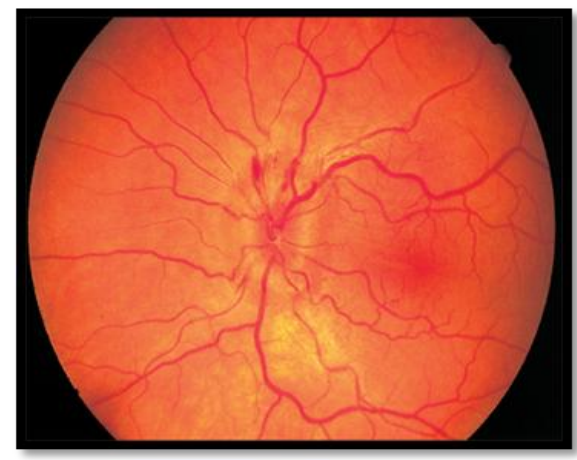

Disc hyperemia

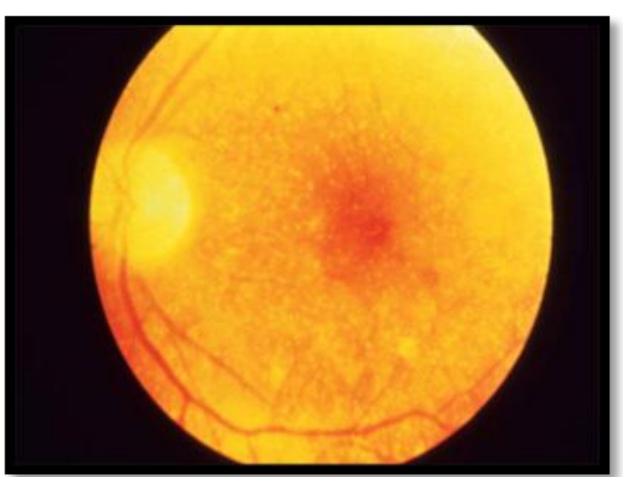

RPE mottling

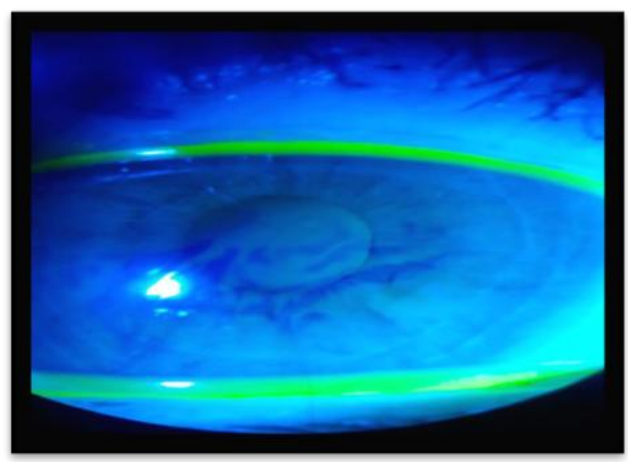

TBUT

Table 4: Thalassemic Children with Ocular Findings

\begin{tabular}{|c|c|c|c|c|c|c|c|}
\hline $\begin{array}{l}\text { AGE } \\
\text { (years) }\end{array}$ & GENDER & $\begin{array}{c}\text { MEAN } \\
\text { SERUM } \\
\text { FERRITIN } \\
(\mathrm{ng} / \mathrm{ml})\end{array}$ & $\begin{array}{l}\text { MEAN } \\
\text { DAILY } \\
\text { DOSE } \\
(\mathrm{mg} / \mathrm{kg})\end{array}$ & $\begin{array}{l}\text { VIS } \\
\text { ACL } \\
\text { RE }\end{array}$ & $\begin{array}{l}\text { ALL } \\
\text { ITY } \\
\text { LE }\end{array}$ & SLIT LAMP & FUNDOSCOPY \\
\hline 6 & M & 1420 & 9.8 & $6 / 9$ & $6 / 6$ & Normal & Normal \\
\hline 9 & $\mathrm{~F}$ & 2978 & 16.5 & $6 / 6$ & $6 / 6$ & OSD & Normal \\
\hline 9 & $\mathrm{~F}$ & 2887 & 18.8 & $6 / 6$ & $6 / 6$ & OSD & Normal \\
\hline 10 & M & 4657 & 10.7 & $6 / 6$ & $6 / 6$ & Normal & RPE mottling \\
\hline 10.5 & $\mathrm{~F}$ & 2800 & 31.8 & $6 / 12$ & $6 / 18$ & $\begin{array}{l}\text { Lenticular } \\
\text { opacity }\end{array}$ & $\begin{array}{l}\text { Blurred optic disc margins, } \\
\text { vessels tortousity }\end{array}$ \\
\hline 11 & M & 3589 & 21.3 & $6 / 6$ & $6 / 6$ & Normal & Normal \\
\hline 12 & $\mathrm{~F}$ & 3890 & 30.5 & $6 / 12$ & $6 / 9$ & OSD & Normal \\
\hline 13 & M & 5400 & 32.4 & $6 / 6$ & $6 / 6$ & OSD & Blurred optic disc margins \\
\hline 13 & M & 4595 & 24.6 & $6 / 6$ & $6 / 6$ & OSD & Normal \\
\hline 15 & $\mathrm{~F}$ & 5200 & 32.8 & $6 / 9$ & $6 / 9$ & OSD & Vessels tortousity \\
\hline 18 & $\mathrm{~F}$ & 5560 & 35.6 & $6 / 12$ & $6 / 9$ & $\begin{array}{l}\text { Lenticular } \\
\text { opacity }\end{array}$ & Normal \\
\hline 18 & $\mathrm{~F}$ & 5774 & 38.5 & $6 / 18$ & $6 / 12$ & OSD & Normal \\
\hline
\end{tabular}

\section{Discussion}

In a resource poor country like India, definitive therapy like stem cell therapy is beyond the reach of majority of the children. These children are on multiple blood transfusions, giving rise to iron over load. Iron overload affects all the organs in 
the body including the eyes. Frequency of ocular involvement in our study was $40 \%$, Gartagantis et al. reported figures of $41.3 \%$, Gaba A et al. reported ocular involvement in $71.4 \%$ while Taneja et al. reported figures of $58 \%$ of subjects in their respective studies ${ }^{3,4}$. Visual acuity was affected in $50 \%$ patients in our study while in Gaba et al. study, the figure was $70 \%$ and Taneja et al. study, this figure was $67 \%$.

Prabhjot Kaur Sekhon et al conducted an study among 75 Beta thalassemia children and showed that the most common eye changes were seen in Retina $(n=24)$, Iris $(n=26)$ and len $s(n=24)$. Corneal dryness, lenticular opacities, disc atrophy and thinning were observed in children with Beta Thalassemia and on blood transfusions. These changes increased with duration of disease ${ }^{5}$. Gosai DK et al conducted a study in which most of the ocular changes of beta thalassemia are attributed to the course and severity of the disease. Reduction in serum iron and serum Ferritin levels by iron- chelating agents and regular ocular examination to look for side-effects of such agents can aid in preventing or delaying ocular complications ${ }^{6}$.

\section{Limitations}

\section{Small sample size}

It cannot conclusively establish whether ocular changes are a result of the disease or due to iron- chelating agents. This requires stoppage of chelation therapy.

\section{Conclusion}

Children with beta-Thalassemia develop various eye problems and Ocular changes are attributed to the course and severity of the disease. Therefore, beta thalassemia children should be screened periodically to enable early detection and delay of ocular changes.

\section{Reference}

1. Lokeshwar MR, Shah N, Kanika S, Manglani M. IAP textbook of paediatrics.3rd edition: Jaypee publishers.2006:622-630.

2. Modell B, Darlison M. Global epidemiology of heamoglobin disorders and derived service indicators. Bull world health organ.2008;86:480-7.

3. Taneja R, Malik P, Sharma M, Agarwal MC. Multiple transfused thalassemia major: Ocular manifestations in a hospitalbased population: Indian J Opthalmol. 2010;58(2):123-30.

4. Gaba A, Souza PD, Chandra J, Narayan S, Sen S Ocular abnormalities in patients with betaThalassemia. Am J Ophthalmol. 1998;108:699-703.

5. Kumble D, Sekhon PK, Gayathri DC.Ocular involvement in beta thalassemia major: a prospective study in Indian cohort. Int J Contemp Pediatr, 2017;4(3):780-82.

6. Gosai DK, Mehariya KM, GosaiJB. Study of ocular manifestations in children ofthalassemia. Int $J$ Res Med Sci 2014;2:695-8. 